\title{
Physicochemical Properties of Moringa oleifera Seeds and Their Edible Oil Cultivated at Different Regions in Egypt
}

\author{
Hassan Barakat ${ }^{1,2 *}$, Galal A. Ghazal ${ }^{1}$ \\ ${ }^{1}$ Department of Food Technology, Faculty of Agriculture, Benha University, Benha, Egypt \\ ${ }^{2}$ Food Science and Human Nutrition Department, College of Agriculture and Veterinary Medicine, \\ Qassim University, Buraidah, Saudi Arabia \\ Email: "hassan.barakat@fagr.bu.edu.eg
}

Received 16 April 2016; accepted 27 May 2016; published 30 May 2016

Copyright (c) 2016 by authors and Scientific Research Publishing Inc.

This work is licensed under the Creative Commons Attribution International License (CC BY). http://creativecommons.org/licenses/by/4.0/

(c)

\begin{abstract}
Moringa oleifera is a plant that successfully grows recently in Egypt and has rich of nutrients seeds with valuable content of edible oil. The present study aimed at determining the physicochemical properties of moringa seeds and their extracted oil of which cultivated at different regions in Egypt. Obtained results revealed that protein, lipid, ash, fiber and total carbohydrate contents were in range of $34.51 \%-36.5 \%, 28.62 \%-30.06 \%, 4.22 \%-5.06 \%, 10.92 \%-12.16 \%$ and $19.00 \%$ - 20.29\%, respectively. Consequently, caloric value was around $450.36-451.32 \mathrm{kcal} 100 \mathrm{~g}^{-1}$ for dried moringa seeds. As confirmed, dried moringa seeds are considered as a rich source of dietary minerals. TPCs content of $M$. oleifera seed were ranged from 16.9 - $18.5 \mathrm{mg} \mathrm{GAE}^{-1} \mathrm{dw}$. The antioxidants activity was in a range of $0.17-0.28 \mu \mathrm{mol} \mathrm{TE} \mathrm{g}^{-1} \mathrm{dw}$ (DPPH scavenging activity) and was in a range of 4.19 - $6.29 \mu \mathrm{mol} \mathrm{TE}^{-1} \mathrm{dw}$ (DPPH scavenging activity). The chlorophyll $a$, chlorophyll $b$, carotenoids, flavonoids and flavonols contents were ranged from 0.93 to $1.78,4.89$ to 8.41 , 13.53 to $19.56 \mathrm{mg} \mathrm{g}^{-1} \mathrm{dw}, 3.30$ to 5.40 and 2.30 to $4.10 \mathrm{mg} \mathrm{QE} \mathrm{g}^{-1} \mathrm{dw}$, respectively. Obviously, the individual essential amino acids (EAAs) and nonessential amino acids (NEAAs) recorded higher contents when compared to referenced protein. Total AA showed in triple amount in moringa protein when compared FAO standard. The acid value, iodine value, unsaponificable matter, peroxide value, refractive index, saponification value of cold pressed moringa seeds oil found to be 0.29 - $0.37 \mathrm{mg} \cdot \mathrm{g}^{-1}, 65.7-67.5,0.60$ to $0.74 \mathrm{~g} 100 \mathrm{~g}^{-1}, 1.67-2.47 \mathrm{mEq} / \mathrm{Kg}, 1.4607$ - $1.4613,171.7$ to $178.3 \mathrm{mg} \mathrm{KOH} \mathrm{g}^{-1}$, respectively. Clearly, the unsaturated fatty acids (USFA) contents of $M$. oleifera edible oils were $77.14 \%-84.98 \%$, especially oleic $(73.30 \%-79.58 \%)$. On contrary, the saturated fatty acids (SFA) recorded $15.00 \%-22.83 \%$ where palmitic and stearic acids were the predominant SFA. The results of oil physicochemical parameters were compared with those of commercial oils. It could be illustrated that moringa seeds and its oil considered as a good source for dietary "Corresponding author.
\end{abstract}


nutraceuticals and valuable characteristics for potential nutritional and technological applications.

Keywords

Moringa oleifera, Chemical Composition, Amino Acids, Fatty Acids, Physicochemical Properties

\section{Introduction}

A strong and rapidly growing Moringa oleifera Lamarck (fam. Moringaceae) tree is widely cultivated due to its high adaptability to environmental conditions [1]. It's considered as one of the most useful trees in the world because almost all parts of this plant can be used as in food, in medicines and for industrial purposes [2]. In many countries, there are huge efforts to spread the use and cultivation of M. oleifera, since it is a significant source of fats, proteins, beta-carotene, vitamin C, iron, potassium, and other nutrients with low toxicity of seeds and leaves [3]. For these reasons, some parts of this plant have drawn much attention and have been studied for its various biological activities, including antiatherosclerotic [4], immune-boosting [5], anticardiovascular diseases [6], antiviral [7], antioxidant and antimicrobial [8], anti-inflammatory [9] properties and tumor suppressive effects in skin papillomagenesis, hepatocarcinoma cancer, colon cancer, and myeloma [7] [10]-[12]. The most recent studies on $M$. olefiera are using the crude protein from the dried and green pod in animal feeding [13], while no brillient studies have been achieved to M. olefiera seed in human nutrition so far. Although its leaves represent an important source of proteins, the nutritional quality depends on the absolute and relative contents of essential amino acids and its bioavailability after digestion and absorption. Pinto et al. [14] demonstrated that vegetable proteins are less susceptible to in vivo digestion than animal proteins. The low content of sulfur amino acids, compact structure, presence of non-protein components (dietary fiber, tannins, phytic acid) and antiphysiological proteins (protease inhibitors, lectins) can affect digestion. Teixeira et al. [1] found that whole leaf flour contained $28.7 \%$ crude protein, $7.1 \%$ fat, $10.9 \%$ ashes, $44.4 \%$ carbohydrate and $3.0 \mathrm{mg} 100 \mathrm{~g}^{-1}$ calcium and $103.1 \mathrm{mg} 100 \mathrm{~g}^{-1}$ iron. The protein profile revealed levels of 3.1\% albumin, $0.3 \%$ globulins, $2.2 \%$ prolamin, 3.5\% glutelin and $70.1 \%$ insoluble proteins. Otherwise, the most recent investigations reported that a flocculating protein (6.5 kDa, IEP pH 10) from the seeds of M. oleifera was isolated and purified. Amino acid analysis and sequencing showed high contents of glutamine, arginine and proline, and a total of 60 residues [15]-[18]. Moreover, Mo-CBP3 is an antifungal protein produced by M. oleifera which has been investigated as potential candidate for developing transgenic crops [14]. Freire et al. [17] found that Mo-CBP3 is a chitin-binding protein that inhibits the germination and mycelial growth of phytopathogenic fungi. This protein is highly thermostable and resistant to $\mathrm{pH}$ changes, and therefore may be useful in the development of new antifungal drugs.

The oil concentration in moringa seed was ranged from $25.8 \%$ to $31.2 \%$ [19]. The physicochemical properties and oxidative stability of extracted oil from seeds of M. oleifera recorded that cold pressed oil contains high levels of $\beta$-sitosterol (up to 50.07\%), stigmasterol (up to 17.27\%), and campesterol (up to $15.13 \%$ ). Moreover, $\alpha, \gamma$, and $\sigma$-tocopherols were detected up to levels of $105.0,39.54$, and $77.60 \mathrm{mg} / \mathrm{kg}$ of oil, respectively [19]. The fatty acids profile of M. oleifera oil was found to contain high levels of unsaturated fatty acids, especially oleic (up to 75.39\%). The dominant saturated acids were behenic up to 6.73\% and palmitic up to 6.04\% [19] [20]. The high oleic acid content also provides good stability to M. oleifera seed oil. It had a good thermal stability. Surly, the oxidative stability and frying stability of cold pressed M. oleifera Jaffna variety seed oil was better than commercial raw and refined groundnut oils, respectively. Based on the present findings, M. oleifera Jaffna variety seed oil has shown enough promise to be considered as more stable and healthy substitute for commercial groundnut oil as a cooking and frying medium [21]-[24]. Moreover, nine fatty acids were detected where oleic acid was found in the largest amount, followed by palmitic acid and behenic acid. The crude, neutralized, and degummed oils showed high primary oxidation stability, while the bleached oil had a low incidence of secondary oxidation [21] [25]. Cold pressed (CP) and hexane extracted (HE) moringa seed oils were evaluated for their physicochemical and stability characteristics. The iodine value, saponification value and unsaponifiable matter of CP and HE were found to be 67.8 and $68.5 \mathrm{~g} \mathrm{I}_{2} 100 \mathrm{~g}^{-1}$ oil, 190.4 and $191.2 \mathrm{mg} \mathrm{KOH} \mathrm{g}^{-1}$ oil and 0.59 and $0.65 \%$, respectively. The total tocopherols of CP and HE were found to be 95.5 and $90.2 \mathrm{mg} \cdot \mathrm{Kg}^{-1}$. The fatty acid composition of CP and HE showed oleic acid as the major fatty acid (78\% - 79\%). The oxidative, thermal and frying stabilities of CP were compared with commercial raw and refined groundnut oil (GNO). The CP was of 
adequate thermal stability and better oxidative stability as it showed 79\% lesser peroxide formation than GNO. The frying stability of CP was better as it showed lower increase in free fatty acid (28\%), peroxide value (10 meq $\mathrm{O}_{2} \mathrm{Kg}^{-1}$ ) and color (25\%) than RGNO (48\%, 22 meq $\mathrm{O}_{2} \mathrm{~kg}^{-1}$ and 52\% respectively) after frying [26]. Recently in Egypt and due to its use into the herbal tea, the current study had focused on characterization of $M$. oleifera seeds and their extracted oil for their bioactive compounds especially with antioxidant and antimicrobial activities. Considering its advantages, the scientific assessment of its potential uses as a new product in Egypt markets as an alternative nutritional source is convenient and necessary. Therefore, the objectives of current work were to determine the physicochemical properties of $M$. oleifera seeds cultivated at different regions in Egypt regarding the chemical, phytochemical composition, antioxidant capacity, amino acids profile of extracted seeds. Moreover, the physicochemical properties and fatty acids composition of moringa seeds edible oil have been investigated to assess their nutritional aspects.

\section{Materials and Methods}

\subsection{Moringa Seeds and Edible Oil Preparation}

The seeds of $M$. oleifera were collected from trees of the main three different cultivation area located in [Asuit, Ismalia, and Monofya Governorates, Egypt]. The same age seeds collected from same age trees were dried at $35^{\circ} \mathrm{C}-40^{\circ} \mathrm{C}$ in van air circulating oven till dryness. The dried seeds were crushed in a knife mill to obtain homogenes seed particles. Subsequently, the crused seeds were mechanically pressed to extract the edible oil then filtered and kept in dark bottles with airtight lids under cooling temperature until being used. Dried raw seeds, extracted oil and extracted pomace cake (EPC) was collected and kept under cooling for analysis.

\subsection{Proximate Chemical Composition and Minerals Content}

The dried seeds were subjected to the chemical analysis (moisture, crude protein, crude lipids, ash, crude fibre according to methods of A.O.A.C. [27] accordingly, the caloric value had been calculated relatively according to obtained results of proximate chemical composition A.O.A.C. [27]. However, the available carbohydrates content was determined by defference according to Merrill and Watt [28]. The minerals content includingsodium, potassium, and calcium was determined in EPC using flame photometry while magnesium, iron, copper, manganese, zinc and selenium contents were determined by atomic absorption spectroscopy according to A.O.A.C. [27]. A standard colorimetric method was applied for phosphorus as mentioned by Borah et al. [29].

\subsection{TPC Determination}

Ten $g$ of re-defatted EPC dried powder was mixed with $50 \mathrm{ml}$ of $70 \%$ methanol (v/v). The mixes were shaken vigorously in a dark bottle for $100 \mathrm{~min}$ at $100 \mathrm{rpm}$. After centrifugation at $3225 \times \mathrm{g}$ for $10 \mathrm{~min}$, the supernatant was collected and the residue was re-extracted twice with $25 \mathrm{ml} \mathrm{70 \%} \mathrm{methanol} \mathrm{for} \mathrm{total} \mathrm{phenolic} \mathrm{content} \mathrm{and}$ antioxidant activity determination. To avoid oxidation, all extracts were stored in the dark at $-20^{\circ} \mathrm{C}$ and analyses were performed within $48 \mathrm{~h}$. The TPC of Moringa EPC powder was determined according to Folin-Ciocalteu spectrophotometric method [30]. The measurements were compared to a standard curve of prepared gallic acid (GA) solution, and the total phenolic content was expressed as milligrams of gallic acid equivalents (GAE) per gram of dried sample (mg of GAE $\mathrm{g}^{-1} \mathrm{dw}$ ).

\subsection{Antioxidant Activity Determination}

\subsubsection{The DPPH Scavenging Activity Assay}

The radical scavenging activity using DPPH reagent (1,1-diphenyl-2-picrylhydrazyl) for moringa EPC extracts have been carried out using modified method by Barakat and Rohn [30]. Each EPC extract $(0.1 \mathrm{ml})$ was added to $2.9 \mathrm{ml}$ of $6 \times 10^{-5}$ molmethanolic solution of DPPH. The absorbance at $517 \mathrm{~nm}$ was measured after the solution had been allowed to stand in the dark for $60 \mathrm{~min}$. The Trolox calibration curve was plotted as a function of the percentage of DPPH radical scavenging activity. The final results were expressed as micromoles of Trolox equivalents (TE) per gram ( $\left.\mu \mathrm{mol} \mathrm{TE} \mathrm{g}^{-1} \mathrm{dw}\right)$.

\subsubsection{ABTS Scavenging Activity Assay}

The radical scavenging activity (RSA) of the different moringa EPC against the stable ABTS radical cation was 
measured using the method of Lu et al. [31]. A Trolox calibration curve was plotted as a function of the percentage of ABTS radical cation scavenging activity. The final results were expressed as micromoles of Trolox equivalents (TE) per gram of dried EPC ( $\mu \mathrm{mol}$ of $\left.\mathrm{TE} \mathrm{g}^{-1} \mathrm{dw}\right)$.

\subsection{Phytochemicals Analysis}

\subsubsection{Total Carotenoids Determination}

According to Yuan et al. [32]; $5 \mathrm{~g}$ of each defatted moringa EPC were extracted with a mixture of acetone and petroleum ether $(1: 1, \mathrm{v} / \mathrm{v})$ repeatedly using the mortar and pestle until a colorless residue was obtained. The upper phase was collected and combined with crude extracts after washed for several times with water. The extracts were made up to a known volume with petroleum ether. Total carotenoids content was determined by recording the absorbance at $451 \mathrm{~nm}$ with a spectrophotometer. Total carotenoids were calculated and expressed as $\mathrm{mg} \mathrm{g}^{-1} \mathrm{dw}$.

\subsubsection{Flavonoids and Flavonols Determination}

The total flavonoids content of moringa EPC were determined according to the method of Mohdaly et al. [33]. A $0.5 \mathrm{ml}$ aliquot of $2 \% \mathrm{AlCl}_{3}$ ethanolic solution was added to $0.5 \mathrm{ml}$ of the extracts and mixed well. After keeping for $1 \mathrm{~h}$ at room temperature, the absorbance at $420 \mathrm{~nm}$ was measured. A yellow color indicates the presence of flavonoids. The total flavonoids content were expressed as mg quercetin equivalent (QE) per $100 \mathrm{gdw}$. The total flavonols content were determined according to Kumaran and Karunakaran [34]. A $0.6 \mathrm{ml}$ aliquot of 2\% $\mathrm{AlCl}_{3}$ ethanolic solution was added to $0.6 \mathrm{ml}$ of each extract and $0.8 \mathrm{ml}$ of a $5 \%$ aqueous sodium acetate solution were added. After mixing and keeping for $2.5 \mathrm{~h}$ at room temperature, the absorbance at $440 \mathrm{~nm}$ was measured. Total flavonols content were expressed as mg quercetin equivalent (QE) per $100 \mathrm{~g} \mathrm{dw}$.

\subsection{Amino Acids Determination}

The amino acids profile was carried out on the precipitated protein from defatted moringa EPC after hydrolysis by $6.0 \mathrm{~N} \mathrm{HCl}$ for $24 \mathrm{~h}$ at $110^{\circ} \mathrm{C}$ in evacuated ampoules. Quantitative determination of amino acids were carried out by Biochrome 30 instruction manual (Analyzer used), 2005. EZ chrome manual (software for data collection and processing), 2004 according to A.O.A.C. [35].

\subsection{Determination of the Physicochemical Parameters and Fatty Acids Composition of Moringa Seeds Oil}

\subsubsection{Determination of Physicochemical Properties}

Physicochemical properties of extracted oils from moringa seeds oil were determined. Specific gravity and refractive index were determined according to A.O.A.C. [37]. However, acid and peroxide values, iodine and saponification numbers and nonsaponifiable matters were determined according to methods described by Habib [36].

\subsubsection{Determination of Fatty Acid Composition}

Derivatization procedure: Total fatty acid fractions were methylated according to Aldai, Osoro [37]. The methyl esters of fatty acids (FAs) obtained from moringa seeds oil were analyzed with a gas liquid chromatography equipped with a dual flame ionization detector. For methylation of free FAs, samples were dried under $\mathrm{N}_{2}$ at $40^{\circ} \mathrm{C}$ then dissolved in $1 \mathrm{ml}$ of methanol: toluene $(2: 1, \mathrm{v} / \mathrm{v})$ and vortexed for $5 \mathrm{~min}$. At this stage, methylation reagent was added in molar excess using $120 \mu \mathrm{l} n$-hexane and the reaction proceeded at $40^{\circ} \mathrm{C}$ for $10 \mathrm{~min}$ in opened tubes. The samples were dried again under gentle stream of $\mathrm{N}_{2}$ at $40^{\circ} \mathrm{C}$ for approximately 20 min. Finally, each sample was reconstituted in $2 \mathrm{ml}$ of $n$-hexane (with $50 \mathrm{ppm}$ of BHT), centrifuged at $20.000 \times g$ for $5 \mathrm{~min}$ at $7^{\circ} \mathrm{C}$ then transferred into vials and kept at $-20^{\circ} \mathrm{C}$. Before GLC injection, samples were diluted in $1 \mu l$ $n$-hexane then injected into GLC column and run under an optimized temperature program with optimized gas flow rate.

GLC equipment and program: Varian Star CX3400 GLC (Varian, Spain) equipped with a FID detector, an automatic sample injector (SPI) in one column mode and a Chrompak CP-SIL 88 for FA methyl esters (FAMEs) (WCOT FUSEDSILICA $100 \mathrm{~m} \times 0.25 \mathrm{mmd} 0.2 \mu \mathrm{m}$ film thickness) with retention gap (FUSED SILICATUBING $4 \mathrm{~m} \times 0.25 \mathrm{~mm}$ i.e., Methyl deactivated) was used. It's used as the carrier gas with a column head 
pressure of $355 \mathrm{kPa}$ and a flow rate of approximately $2 \mathrm{ml} \cdot \mathrm{min}^{-1}$ measured at $100^{\circ} \mathrm{C}$. The GLC conditions were as follows: $\left(100^{\circ} \mathrm{C}\right.$, at $2^{\circ} \mathrm{C} \mathrm{min}^{-1}$ to $170^{\circ} \mathrm{C}$, hold for $15 \mathrm{~min}$, at $0.5^{\circ} \mathrm{C} \mathrm{min}^{-1}$ to $180^{\circ} \mathrm{C}$, at $10^{\circ} \mathrm{C} \mathrm{min}^{-1}$ to $200^{\circ} \mathrm{C}$ and hold for $10 \mathrm{~min}$ at $2^{\circ} \mathrm{C} \mathrm{min}{ }^{-1}$ to $230^{\circ} \mathrm{C}$ then hold for $10 \mathrm{~min}$ ); injection temperature was $250^{\circ} \mathrm{C}$; detector temperature was $300^{\circ} \mathrm{C}$. Results were evaluated with a conventional integrator program (Saturn GC Workstation Software ver., 5.51).

\subsection{Statistical Analysis}

The statistical analysis was carried out using SPSS program with multi-function utility regarding to the experimental design under significance level of 0.05 for the whole results. Multiple comparisons applying LSD was carried out according to Steel et al. [38].

\section{Results and Discussion}

\subsection{Proximate Chemical Composition of M. oleifera Seeds}

Directly after the appropriate samples have been collected and similarly dried and milled then were subjected to the analysis. The proximate chemical composition of moringa seeds comes from cultivated plants at different regions were carried out and the data were illustrated in Table 1 . It could be observed that there are no significant differences $(p>0.05)$ among dried moringa seeds in their moisture, protein, lipids and available carbohydrates contents. On the contrary, there are significant difference was observed $(p<0.05)$ among the analysed moringa seeds in ash and fiber contents. Interestingly, all moringa seeds seem to be a good source of crude protein and lipids. The protein, lipid, ash, fiber and total carbohydrate contents were in range of $34.51 \%-36.5 \%$, $28.62 \%-30.06 \%, 4.22 \%-5.06 \%, 10.92 \%-12.16 \%$ and $19.00 \%-20.29 \%$, respectively. The data indicate that ash and crude fiber contents were significantly higher in M. Oraby than both M. Asuit and M. Monofya. It is worth mentioning that higher protein, lipid and available carbohydrates contents exude relevant caloric value around 450.36 - $451.32 \mathrm{kcal} 100 \mathrm{~g}^{-1}$ for dried moringa seeds with no observed significant difference $(p>0.05)$.

The obtained results are closely pertinent to observed results by [23] [39]-[41]. However, the variation of obtained results in the chemical composition might be related to samples collection, preparation and cultivation conditions [1] [39] [42].

\subsection{Minerals Content of M. oleifera EPC}

The minerals content as macro-elements such as (sodium, potassium, calcium, phosphorus and magnesium) and

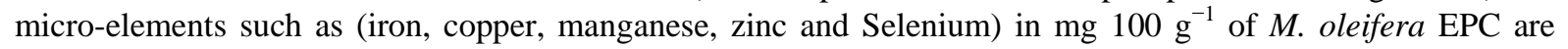
given in Table 2. At the first glans, no selenium content had been detected in all analyzed samples. However, so-

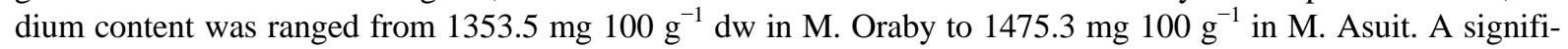
cant difference $(p<0.05)$ was found among all moringa EPC. Potassium content was 1045.2, 1143.8 and 1278.7 $\mathrm{mg} 100 \mathrm{~g}^{-1} \mathrm{dw}$ in M. Monofya, M. Oraby and M. Asuit, respectively. Calcium content recorded 254.2, 353.7 and $478.6 \mathrm{mg} 100 \mathrm{~g}^{-1} \mathrm{dw}$ for M. Asuit, M. Oraby and M. Monofya, respectively. M. Oraby exhibited significantly

Table 1. Proximate chemical composition of M. oleifera seeds (mean \pm SE).

\begin{tabular}{|c|c|c|c|}
\hline \multirow{2}{*}{ Chemical composition (\%) } & \multicolumn{3}{|c|}{ Relevant regions moringa seeds } \\
\hline & M. Asuit & M. Oraby & M. Monofya \\
\hline Moisture content & $7.50 \pm 0.65^{\mathrm{a}}$ & $6.57 \pm 0.49^{\mathrm{a}}$ & $6.54 \pm 0.49^{\mathrm{a}}$ \\
\hline Crude protein content ${ }^{\mathrm{dw}}$ & $35.54 \pm 0.85^{\mathrm{a}}$ & $34.51 \pm 0.21^{\mathrm{a}}$ & $36.53 \pm 2.58^{\mathrm{a}}$ \\
\hline Crude lipids content ${ }^{\mathrm{dw}}$ & $29.61 \pm 0.57^{\mathrm{a}}$ & $30.06 \pm 0.55^{\mathrm{a}}$ & $28.62 \pm 0.1^{\mathrm{a}}$ \\
\hline Ash content $\mathrm{d}^{\mathrm{dw}}$ & $4.73 \pm 0.07^{\mathrm{b}}$ & $5.06 \pm 0.03^{\mathrm{c}}$ & $4.22 \pm 0.02^{\mathrm{a}}$ \\
\hline Crude fibers content ${ }^{\mathrm{dw}}$ & $10.92 \pm 0.52^{\mathrm{a}}$ & $12.16 \pm 0.26^{\mathrm{b}}$ & $11.05 \pm 0.61^{\mathrm{a}}$ \\
\hline Available carbohydrates content ${ }^{\mathrm{dw}}$ & $20.03 \pm 1.56^{\mathrm{a}}$ & $19.00 \pm 0.65^{\mathrm{a}}$ & $20.29 \pm 3.15^{\mathrm{a}}$ \\
\hline Caloric value kcal/100 $\mathrm{g}^{\mathrm{fw}}$ & $450.36 \pm 3.83^{\mathrm{a}}$ & $451.09 \pm 3.76^{\mathrm{a}}$ & $451.32 \pm 1.64^{\mathrm{a}}$ \\
\hline
\end{tabular}

dw: dry weight, fw: fresh weight. 
Table 2. Minerals content of M. oleifera PEC (mean \pm SE).

\begin{tabular}{cccc} 
Minerals & \multicolumn{3}{c}{ Minerals content $\left(\mathrm{mg} 100 \mathrm{~g}^{-1} \mathrm{dw}\right)$} \\
\cline { 2 - 4 } Macro-elements & M. Asuit & M. Oraby & M. Monofya \\
Sodium & & & $1430.24 \pm 2.07^{\mathrm{b}}$ \\
Potassium & $1475.31 \pm 11.66^{\mathrm{c}}$ & $1353.52 \pm 8.74^{\mathrm{a}}$ & $1045.24 \pm 24.68^{\mathrm{a}}$ \\
Calcium & $1278.65 \pm 18.75^{\mathrm{c}}$ & $1143.78 \pm 23.02^{\mathrm{b}}$ & $478.63 \pm 13.52^{\mathrm{b}}$ \\
Phosphorus & $254.19 \pm 39.99^{\mathrm{a}}$ & $353.7 \pm 22.24^{\mathrm{a}}$ & $705.27 \pm 10.82^{\mathrm{a}}$ \\
Magnesium & $738.15 \pm 9.71^{\mathrm{ab}}$ & $753.31 \pm 3.31^{\mathrm{b}}$ & $78.32 \pm 1.02^{\mathrm{c}}$ \\
Micro-elements & $64.4 \pm 1.06^{\mathrm{a}}$ & $69.38 \pm 1.39^{\mathrm{b}}$ & $283.79 \pm 6.34^{\mathrm{c}}$ \\
Iron & & & $8.7 \pm 0.89^{\mathrm{a}}$ \\
Copper & $185.28 \pm 1.22^{\mathrm{a}}$ & $207.57 \pm 3.8^{\mathrm{b}}$ & $75.6 \pm 2.19^{\mathrm{a}}$ \\
Manganese & $7.91 \pm 0.46^{\mathrm{a}}$ & $10.07 \pm 0.59^{\mathrm{a}}$ & $92.73 \pm 1.98^{\mathrm{b}}$ \\
Zinc & $91.79 \pm 1.29^{\mathrm{b}}$ & $120.26 \pm 3.9^{\mathrm{c}}$ & $\mathrm{ND}$
\end{tabular}

dw: dry weight, ND: not detected.

higher phosphorus content than M. Monofya. Obviously, M. Monofya exhibited significantly higher magnesium content than either M. Oraby or M. Asuit. In the same context, M. Monofya demonstrated significantly higher iron and zinc contents than both M. Oraby and M. Asuit. In contrary, M. Oraby recorded the highest manganese content among all moringa samples. There is no significant difference had been observed between all moringa samples in copper content. The obtained results reflect that dried moringa seeds cultivated at different regions in Egypt are considered as a rich source of dietary minerals. Comparing the current results with the reviewed minerals resulted it could be illustrated that current results are in harmony with previously mentioned [23] [39]-[41]. However, some few minerals are exhibit higher or lower results than reviewed which reflect the effect of cultivation and environmental conditions as confirmed by [1] [39] [42].

\subsection{Phytochemicals and Antioxidant Capacity of M, oleifera EPC}

Data in Table 3 shows the content of TPC $\left[\mathrm{mg} \mathrm{g}^{-1} \mathrm{dw}\right.$ ] and antioxidant activity $\left[\mu \mathrm{mol} \mathrm{TE} \mathrm{g}{ }^{-1} \mathrm{dw}\right.$ ] of M. oleifera seeds at different regions in Egypt. Moreover, the phytochemicals such as chlorophylls $a \& b$, carotenoids, flavonoids, and flavonols of various moringa EPC samples have been investigated and data are given in the same table. TPC content and antioxidant activity of M. oleifera EPC were ranged from $16.9-18.5 \mathrm{mg} \mathrm{GAE} \mathrm{g}^{-1} \mathrm{dw}$. The evolution of DPPH and ABTS radical scavenging activity of various moringa was assayed using the common DPPH and ABTS assays and results are referred to Trolox equivalent $\mathrm{g}^{-1}\left[\mu \mathrm{mol} \mathrm{TE} \mathrm{g}^{-1}\right]$ and given in Table 3. The antioxidant capacity of determined TPC showed a positive relation depends on the initial content being as high TPC high antioxidant response had been remarked. The result of antioxidants activity (DPPH scavenging activity) noticed no significant difference $(p<0.05)$ among the three moringa samples which was in a range of

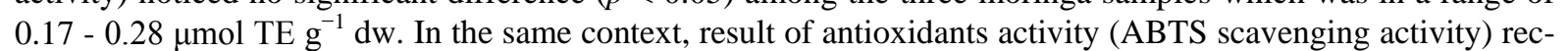
orded also no significant difference $(p<0.05)$ among the three moringa samples which was in a range of 4.19 -

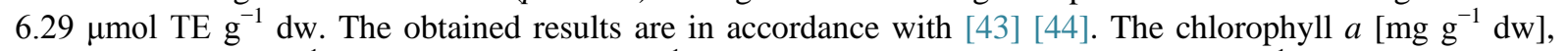
chlorophyll $b$ [mg g ${ }^{-1} \mathrm{dw}$ ], carotenoids [ $\mathrm{mg} \mathrm{g}^{-1} \mathrm{dw}$ ], flavonoids and flavonols [mg QE $\mathrm{g}^{-1} \mathrm{dw}$ ] contents were ranged from 0.93 to $1.78,4.89$ to $8.41,13.53$ to $19.56,3.30$ to 5.40 and 2.30 to 4.10 , respectively (Table 3 ). The obtained results are in agreement with [39] [44]-[46]. Regarding to the phytochemicals contents, there was no significant differences $(p>0.05)$ among the three moringa seeds as they collected carefully from the same part of the trees and from the same harvest even they were dried under the same conditions. These results are a good observation to overview the main differences between M. oleifera cultivated at different regions in Egypt. 
Table 3. Total phenolic compounds and antioxidant activity, chlorophyll $a \& b$, flavonoids and flavonols of $M$. oleifera defatted seeds cultivated at different regions in Egypt (mean \pm SE).

\begin{tabular}{|c|c|c|c|}
\hline \multirow{2}{*}{ Item } & \multicolumn{3}{|c|}{ Relevant regions moringa seeds } \\
\hline & M. Asuit & M. Oraby & M. Monofya \\
\hline TPC [mg GAE g $\left.{ }^{-1 \mathrm{dw}}\right]$ & $17.36 \pm 0.14^{\mathrm{a}}$ & $16.94 \pm 0.12^{\mathrm{a}}$ & $18.45 \pm 0.19^{b}$ \\
\hline Antioxidant activity $\left[\mu \mathrm{mol} \mathrm{TE} \mathrm{g}^{-1 \mathrm{dw}}\right]^{*}$ & $0.19 \pm 0.05^{\mathrm{a}}$ & $0.17 \pm 0.04^{\mathrm{a}}$ & $0.28 \pm 0.05^{\mathrm{a}}$ \\
\hline Antioxidant activity $\left[\mu \mathrm{mol} \mathrm{TE} \mathrm{g}^{-1 \mathrm{dw}}\right]^{* *}$ & $5.78 \pm 0.55^{\mathrm{a}}$ & $4.19 \pm 1.12^{\mathrm{a}}$ & $6.29 \pm 1.25^{\mathrm{a}}$ \\
\hline Chlorophyll $a$ [mg $\left.100 \mathrm{~g}^{-1 \mathrm{dw}}\right]$ & $1.78 \pm 0.1^{\mathrm{b}}$ & $1.15 \pm 0.06^{\mathrm{a}}$ & $0.93 \pm 0.14^{\mathrm{a}}$ \\
\hline Chlorophyll $b$ [mg $100 \mathrm{~g}^{-1 \mathrm{dw}}$ ] & $4.89 \pm 0.36^{\mathrm{a}}$ & $5.22 \pm 0.26^{\mathrm{a}}$ & $8.41 \pm 0.7^{\mathrm{b}}$ \\
\hline Carotenoids [mg $\left.100 \mathrm{~g}^{-1 \mathrm{dw}}\right]$ & $18.79 \pm 3.6^{\mathrm{a}}$ & $13.53 \pm 3.11^{\mathrm{a}}$ & $19.56 \pm 1.78^{\mathrm{a}}$ \\
\hline Flavonoids [mg QE $100 \mathrm{~g}^{-1 \mathrm{dw}}$ ] & $4.60 \pm 0.87^{\mathrm{a}}$ & $3.30 \pm 0.95^{\mathrm{a}}$ & $5.40 \pm 0.45^{\mathrm{a}}$ \\
\hline Flavonols [mg QE $100 \mathrm{~g}^{-1 \mathrm{dw}}$ ] & $2.30 . \pm 0.57^{\mathrm{a}}$ & $4.10 \pm 0.47^{\mathrm{a}}$ & $2.70 \pm 0.13^{\mathrm{a}}$ \\
\hline
\end{tabular}

dw: dry weight, ": BPPH radical scavenging activity (BPPH-RSA), ${ }^{* *}$ : ABTS radical scavenging activity (ABTS-RSA).

\subsection{Amino Acid Composition of M. oleifera Protein}

Surely, amino acid compositional data are only the first in the nutritional assessment of any food protein. The amino acids composition for isolated protein from of M. oleifera is given in Table 4. Obtained data showed that, fifteen amino acids were identified. Obviously, the individual EAAs recorded higher contents than EAAs in referenced hen's egg protein except Lysine in all moringa seeds protein. Leucine remarked to be the highest EAA in all moringa EPC protein while, Lysine recorded the lowest amino acid. The total EAAs found to be in a double fold in moringa EPC protein when compared to hen's egg protein. Likewise, the individual NEAAs recorded higher contents than NEAAs in referenced hen's egg protein. Glutamic and proline acids were presented in all moringa protein in a sensible amount being $\sim 4$ fold more. However, total NEAAs found to be $\sim 4$ fold in moringa seed protein when compared to hen's egg protein. Total AA showed in triple amount in moringa protein when compared to hen's egg (Table 4). Data in Table 5 illustrate the nutritional evaluation of moringa protein. The amount of TEAAs was ranged from 29.74 in M. Asuit to $30.96 \mathrm{~g} 16 \mathrm{~g} \mathrm{~N}$ in M. Monofya which lower content than higher egg' protein according to FAO (1970).

Conversely, TNEAAs was ranged from 62.80 to $63.29 \mathrm{~g} 16 \mathrm{~g} \mathrm{~N}$ which exhibit higher content than egg' protein according to FAO (1970). The EAA:NEAA ratio, EAA:Protein ratio, EAA:Total AA ratio and EAAI\% demonstrated that moringa proteins are lower than egg' proteins according to FAO (1970) (Table 5). As recommended by FAO and WHO, there are two main categories being very important for determining the protein quality, one of them depends on calculating the individual AAs score and comparing them to hen's egg as a standard protein. Screening the all calculated values of moringa proteins, obtained results showed to be very close to the standard values of egg protein. Lysine score being to be in a lower value while Histidine score comes in higher value when compared to egg protein, Table 6. Data in Table 7 shows the certain AAs of moringa protein compared to FAO pattern ( $\mathrm{mg} \mathrm{g}^{-1}$ protein). The certain AAs of moringa protein were (Lysine, Lysine and Lysine), (Therionine, Tyrosine and Therionine) and (Tyrosine, Therionine and Tyrosine) for first, second and third limiting AA of M. Asuit, M. Oraby and M. Monofya, respectively. These results were more or less in agreement with mentioned previously [14] [15] [17] [39] [47] [48].

However, a few research data are available regarding to utilization of moringa protein, even it was available a difference might be found regarding the variation of environment, cultivation and sampling condition could influenced the results. Furthermore, moringa protein may have potential food applications.

\subsection{Physicochemical Properties of M. oleifera Edible Oil}

Not only the physiochemical parameters of moringa seeds oil was measured, but also they compared with soybean, cotton seeds as well as virgin olive oils as edible oils, then data were presented in Table 8 . The acid value of moringa oil was ranged from $0.29 \mathrm{mg} \mathrm{g}^{-1}$ in M. Asuit to 0.37 in M. Monofya. However, the recorded values than acid value of all extracted oil were in under the maximum level of allowed acid number when compared to 
Table 4. Amino acid composition of moringa seeds protein cultivated at three deferent regions in Egypt (mg $\left.100 \mathrm{~g}^{-1} \mathrm{dw}\right)$ comparing with standard protein and amino acids scores.

\begin{tabular}{ccccc}
\hline Amino acid & \multicolumn{3}{c}{ Relevant regions moringa seeds } & Hens egg (FAO 1970) \\
\cline { 2 - 4 } M. Asuit & M. Oraby & M. Monofya & 613 \\
Therionine & 934 & EAA & 972 & 820 \\
Valine & 1452 & 1420 & 1589 & 753 \\
Isoleucine & 1249 & 1280 & 1327 & 1056 \\
Leucine & 2080 & 2112 & 2299 & 498 \\
Tyrosine & 879 & 822 & 981 & 686 \\
Phenylalanine & 1665 & 1700 & 1766 & 835 \\
Lysine & 611 & 626 & 682 & 291 \\
Histidine & 907 & 860 & 953 & 1152 \\
& & NEAA- & 1682 & 916 \\
Aspartic acid & 1637 & 1635 & 1131 & 1525 \\
Serine & 1129 & 1131 & 7215 & 498 \\
Glutamic acid & 7049 & 6895 & 2551 & 397 \\
Proline & 2211 & 2289 & 1953 & 709 \\
Glycine & 1859 & 1822 & 1486 & 730 \\
Alanine & 1425 & 1429 & 5589 & 11,479 \\
Argenine & 5337 & 5204 & 32,176 & 5552 \\
Total amino acids & 30,424 & 30,197 & 10,569 & 5927 \\
Total EAA" & 9777 & 9792 & 21,607 & 12.60 \\
Total NEAA & 20,647 & 20,405 & 34.141 & \\
\% Crude protein & 32.875 & 32.243 & & \\
\hline
\end{tabular}

": Essential amino acids; "': Non-essential amino acid.

Table 5. The nutritional evaluation of moringa seeds protein cultivated at three deferent regions in Egypt.

\begin{tabular}{ccccccc}
\hline \multirow{2}{*}{ Items } & \multicolumn{5}{c}{ Nutritional calculations } \\
\cline { 2 - 7 } & TEAA g/16 N & TNEAA g/16 N & EAA:NEAA Ratio & EAA:Protein Ratio & EAA:Total AA Ratio & EAAI \% \\
\hline M. Asuit & 29.74 & 62.80 & 0.47 & 0.30 & 0.321 & 70.03 \\
M. Oraby & 30.37 & 63.28 & 0.48 & 0.30 & 0.324 & 71.04 \\
M. Monofya & 30.96 & 63.29 & 0.49 & 0.31 & 0.328 & 72.38 \\
Egg $^{*}$ & 44.06 & 47.04 & 0.94 & 0.44 & 0.484 & 100.00 \\
\hline
\end{tabular}

EAA: NEAA: Ratio of essential amino acids to nonessential amino acid. EAA: Protein Ratio: Ratio of essential amino acids to 100 g protein. NEAA: Total AA Ratio: Ratio of essential amino acids to total amino acid. EAAI \%: Essential amino acids index according to FAO.

Table 6. Assessment of individual amino acids to references essential amino acids in hen’s egg protein [mg individual AA/g TEAA].

\begin{tabular}{|c|c|c|c|c|}
\hline \multirow{2}{*}{ Amino acids } & \multicolumn{3}{|c|}{ Relevant regions moringa seeds } & \multirow{2}{*}{ Hens egg score (FAO 1970) } \\
\hline & M. Asuit score & M. Oraby score & M. Monofya score & \\
\hline Therionine & 95.93 & 99.27 & 91.97 & 110.42 \\
\hline Valine & 148.51 & 145.02 & 150.35 & 147.69 \\
\hline Isoleucine & 127.75 & 130.72 & 125.56 & 135.61 \\
\hline Leucine & 212.74 & 215.69 & 217.52 & 190.13 \\
\hline Tyrosine & 89.91 & 83.95 & 92.82 & 89.72 \\
\hline Phenylalanine & 170.30 & 173.61 & 167.09 & 123.53 \\
\hline Lysine & 62.49 & 63.93 & 64.53 & 150.45 \\
\hline Histidine & 92.77 & 87.83 & 90.17 & 52.45 \\
\hline
\end{tabular}

Amino acid score according to $\mathrm{FAO}(1973)=\frac{\text { mg amino acid in } 1 \text { g protein }}{\mathrm{mg} \text { amino acid sugested by FAO } / \mathrm{WHO}} \times 100$. 
Table 7. The certain amino acids in moringa protein compared to FAO pattern $\mathrm{mg} \cdot \mathrm{g}^{-1}$ protein.

\begin{tabular}{ccccc}
\hline \multirow{2}{*}{ Amino acid } & \multicolumn{3}{c}{ Relevant regions moringa seeds } & Suggested amino acid pattern \\
\cline { 2 - 4 } & M. Asuit score & M. Oraby score & M. Monofya score & 40 \\
Therionine & 71.03 & 75.37 & 71.18 & 50 \\
Valine & 88.33 & 88.08 & 93.08 & 40 \\
Isoleucine & 94.98 & 99.25 & 97.17 & 70 \\
Leucine & 90.39 & 93.58 & 96.20 & 35 \\
Tyrosine & 76.39 & 72.84 & 82.10 & 48 \\
Phenylalanine & 105.51 & 109.84 & 107.76 & 55 \\
Lysine & 33.79 & 35.30 & 36.32 & 21 \\
Histidine & 131.38 & 127.01 & 132.92 & - \\
First limiting amino acid & Lysine & Lysine & Lysine & - \\
Second limiting amino acid & Therionine & Tyrosine & Therionine & - \\
Third limiting amino acid & Tyrosine & Therionine & Tyrosine & \\
\hline
\end{tabular}

*According to FAO/WHO AD HOC Committee (FAO, 1973). Amino acid score according to

FAO $(1973)=\frac{\text { mg amino acid in } 1 \text { g protein }}{\text { mg amino acid sugested by FAO } / \text { WHO }} \times 100$. Bold highlighted preferred that the lowest percentage compared to FAO pattern.

Table 8. Physicochemical properties of M. oleifera edible oil extracted from moringa seeds cultivated at different regions in Egypt (mean $\pm \mathrm{SE})$.

\begin{tabular}{|c|c|c|c|c|c|c|}
\hline \multirow{2}{*}{ Parameters } & \multicolumn{3}{|c|}{ Moringa seeds oil } & \multicolumn{3}{|c|}{ Selected reference oils ${ }^{*}$} \\
\hline & M. Asuit & M. Oraby & M. Monofya & Soybean oil & Virgin olive oil & Cotton seeds oil \\
\hline Acid value $\left(\mathrm{mg} \cdot \mathrm{g}^{-1}\right.$ ) & $0.29^{\mathrm{a}} \pm 0.02$ & $0.36^{\mathrm{b}} \pm 0.01$ & $0.37^{\mathrm{b}} \pm 0.01$ & $\leq 0.60$ & $\leq 8$ & $\leq 0.60$ \\
\hline Iodine number ( $\mathrm{g} \mathrm{I}_{2} 100 \mathrm{~g}^{-1}$ ) & $65.67^{\mathrm{a}} \pm 0.54$ & $67.47^{\mathrm{b}} \pm 0.17$ & $65.17^{\mathrm{a}} \pm 0.24$ & $124-139$ & $75-94$ & $100-123$ \\
\hline Unsaponificable matter (g $100 \mathrm{~g}^{-1}$ ) & $0.74^{\mathrm{c}} \pm 0.2$ & $0.60^{\mathrm{a}} \pm 0.3$ & $0.67^{\mathrm{b}} \pm 0.1$ & $\leq 1.5$ & $\leq 1.5$ & $\leq 1.5$ \\
\hline Peroxide value (mEq/Kg) & $2.20^{\mathrm{b}} \pm 0.12$ & $1.67^{\mathrm{a}} \pm 0.07$ & $2.47^{\mathrm{b}} \pm 0.12$ & $\leq 10$ & $\leq 20$ & $\leq 10$ \\
\hline Refractive index at $40^{\circ} \mathrm{C}$ & $1.4610^{\mathrm{a}} \pm 0.00$ & $1.4613^{\mathrm{a}} \pm 0.00$ & $1.4607^{\mathrm{a}} \pm 0.00$ & $1.466-1.470$ & $1.467-1.470$ & $1.458-1.466$ \\
\hline Specific gravity at $25^{\circ} \mathrm{C}$ & $0.918^{\mathrm{b}} \pm 0.002$ & $0.916^{\mathrm{b}} \pm 0.002$ & $0.901^{\mathrm{a}} \pm 0.005$ & $0.919-0.925$ & $0.910-0.916$ & $0.918-0.926$ \\
\hline Saponification number (mg KOH/g oil) & $175.00^{\mathrm{a}} \pm 1.42$ & $171.67^{\mathrm{a}} \pm 1.19$ & $178.33^{\mathrm{b}} \pm 1.19$ & $195-198$ & $184-196$ & $189-198$ \\
\hline
\end{tabular}

reference oils. Surely, the iodine number of moringa oil was lower than references oils. The iodine number of M. Oraby oil was significantly higher than both M. Asuit and M. Monofya oils. By comparing the nonsaponification matters in moringa oil with reference oils, moringa oils recorded lower value than all reference oils; despite M. Asuit was recorded higher value than both moringa oils, significantly. The mean of nonsaponification mat-

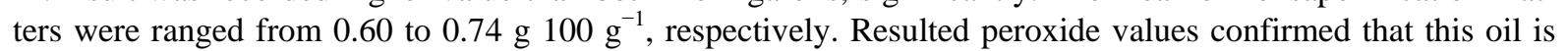
freshly expressed being exhibited lower values than the maximum remarked level with reference oils. However, PV of M. Monofya oil was higher than M. Asuit and M. Oraby, significantly. In addition, moringa oil recorded refractive index in accordance with all reference oils which ranged from $1.4607-1.4613$. Regarding the specific gravity, moringa oil were in homogeneity with reference oils Table 8.

The saponification number of moringa oil was ranged from 171.7 to $178.3 \mathrm{mg} \mathrm{KOH} \mathrm{g}^{-1}$. M. Monofya oil was significantly higher than both moringa oils. The physiochemical characteristics of moringa oils are resembles more or less to all referenced oils. Thus, moringa oils can be used as edible oils after biological investigation being concerned. These results are in agreement with the published results by [19] [21] [22] [25] [26] [49] [50].

\subsection{Fatty Acids Composition of M. oleifera Edible Oil}

In order to examine the lipid composition, fatty acids fractionations of M. oleifera edible oils of three cultivation 
region in Egypt was done and data were illustrated in Table 9. Obtained data observed that eleven fatty acids have been identified. Clearly, the unsaturated fatty acids (USFA) contents of M. oleifera edible oils were 77.14\%, 84.98\% and 78.99\% for M. Asuit, M. Oraby and M. Monofya, respectively. Nonetheless, the percentage of saturated fatty acids (SFA) in M. oleifera edible oils recorded 22.83\%, $15.00 \%$ and $20.98 \%$ for M. Asuit, M. Oraby and M. Monofya, respectively. Indeed, in all M. oleifera edible oils palmitic and stearic acids were the predominant SFA. In addition, the value of palmitic acid in M. oleifera edible oils was ranged from 5.66\% $6.09 \%$. On the contrary, theoleic acid was the major USFAin all M. oleifera edible oils which ranged from $73.30 \%$ $-79.58 \%$.

Furthermore, oleic acid recorded the highest USFA in M. Oraby to be $79.58 \%$. Otherwise, stearic acid scored the highest SFA in M. Asuit to be $7.94 \%$. For the best of our knowledge and from parallel comparison of $M$. oleifera oils with cotton seeds, soy bean and olive virgin edible oils, the M. oleifera recorded lower palmitic acid and higher stearic, arachidic and behenic acids than edible oils and can be considered as one of the richest source of oleic acid with considerable higher ratio of USFA/AFA than found in cotton seeds oil, olive and soybean oils (Table 9). Undoubtedly, the possibility of using the $M$. oleifera oils for supporting or mixed with other oils could be a principle of $M$. oleifera waste valorization. These results are agreement with the previous studies [19] [22] [24]-[26] [50].

\section{Conclusion}

Data obtained in present study could be useful for determining the chemical characteristics, minerals content and phytochemicals of moringa seeds which came from the main cultivation region in Egypt. Phytochemicals and their antioxidant exhibited promising potential applications in food processing industries. The amino acids content demonstrated a high potential application of extracted seeds cake in human and animal nutrition being the highly nutrition value of its protein. Physicochemical properties of moringa seeds oil recorded that moringa seeds oil had a promising potential application in nutrition aspects. The higher content of unsaturated fatty acids may present a healthy impact of moringa seeds oil in human nutrition.

Table 9. Fatty acids composition of M. oleifera edible oil by GLC analysis.

\begin{tabular}{|c|c|c|c|c|c|c|}
\hline \multirow{2}{*}{ Fatty acid } & \multicolumn{3}{|c|}{ Fatty acid \% } & \multicolumn{3}{|c|}{ Fatty acid \% in reference oils ${ }^{*}$} \\
\hline & M. Asuit & M. Oraby & M. Monofya & Cotton seeds oil & Soybean oil & Olive oil \\
\hline Palmitic acid (C16:0) & 6.09 & 5.66 & 6.44 & $21.40-26.40$ & $8.0-13.50$ & $7.50-20$ \\
\hline Palmitoleic acid (C16:1) & 1.80 & 1.43 & 1.92 & $0.05-1.20$ & $0.05-0.20$ & $30-3.50$ \\
\hline Margaric acid (C17:0) & 0.08 & 0.09 & 0.09 & $0.05-0.10$ & $0.05-0.10$ & $0.0-0.30$ \\
\hline Heptadecenoic acid (C17:1) & 0.10 & 0.06 & 0.06 & $0.05-0.10$ & $0.05-0.10$ & $0.0-0.30$ \\
\hline Stearic acid (C18:0) & 7.94 & 4.79 & 7.12 & $2.10-3.30$ & $2.0-5.40$ & $0.50-5.0$ \\
\hline Oleic acid (C18:1) & 73.30 & 79.58 & 73.51 & $14.70-21.70$ & $170-30.0$ & $55.0-83$ \\
\hline Linoleic acid (C18:2) & 0.59 & 0.58 & 0.59 & $46.70-58.20$ & $48.0-59.0$ & $3.50-21$ \\
\hline Linolenic acid (C18:3) & 0.17 & 0.15 & 0.17 & $0.05-0.40$ & $4.50-11.0$ & $0.0-1.0$ \\
\hline Arachidic acid (C20:0) & 5.10 & 1.57 & 4.71 & $0.20-0.50$ & $0.10-0.60$ & $0.0-0.60$ \\
\hline Gadoleic acid (C20:1) & 1.18 & 3.16 & 2.74 & $0.05-0.10$ & $0.05-0.50$ & $0.0-0.40$ \\
\hline Behenic acid (C22:0) & 3.62 & 2.89 & 2.62 & $0.05-0.60$ & $0.05-0.70$ & $0.0-0.20$ \\
\hline Unknown & -- & -- & -- & -- & -- & -- \\
\hline SFA & 22.83 & 15.00 & 20.98 & $23.85-31.00$ & $10.25-20.80$ & $8.0-26.30$ \\
\hline USFA & 77.14 & 84.98 & 78.99 & $61.60-81.70$ & $69.65-100.80$ & $61.50-109.20$ \\
\hline USFA/SFA & 3.33 & 5.67 & 3.76 & $2.50-2.60$ & $4.80-6.70$ & $4.10-7.60$ \\
\hline
\end{tabular}

${ }^{*}$ Results according to Egyptian Standards [51], Egyptian Standards [52], Egyptian Standards [53]. 


\section{Acknowledgements}

The authors are very glad to acknowledge Moringa Misr Company, for providing different samples and technical assistance during harvesting and drying of the M. oleifera seeds insuring the long experience of this company in Moringa production.

\section{References}

[1] Teixeira, E.M., Carvalho, M.R., Neves, V.A., Silva, M.A. and Arantes-Pereira, L. (2014) Chemical Characteristics and Fractionation of Proteins from Moringa oleifera Lam. Leaves. Food Chemistry, 147, 51-54. http://dx.doi.org/10.1016/j.foodchem.2013.09.135

[2] Anwar, F., Latif, S.F.M., Ashraf, M.F.A.H. and Gilani, A.H. (2007) Moringa oleifera: A Food Plant with Multiple Medicinal Uses. Phytotherapy Research, 2, 17-25. http://dx.doi.org/10.1002/ptr.2023

[3] Saini, R.K., Shetty, N.P., Prakash, M. and Giridhar, P. (2014) Effect of Dehydration Methods on Retention of Carotenoids, Tocopherols, Ascorbic Acid and Antioxidant Activity in Moringa oleifera Leaves and Preparation of a RTE Product. Journal of Food Science and Technology, 51, 2176-2182. http://dx.doi.org/10.1007/s13197-014-1264-3

[4] Chumark, P., Khunawat, P., Sanvarinda, Y., Phornchirasilp, S., Morales, N.P., Phivthong-ngam, L., Ratanachamnong, P., Srisawat, S. and Pongrapeeporn, K.-U.S. (2008) The in Vitro and ex Vivo Antioxidant Properties, Hypolipidaemic and Antiatherosclerotic Activities of Water Extract of Moringa oleifera Lam. Leaves. Journal of Ethnopharmacology, 116, 439-446. http://dx.doi.org/10.1016/j.jep.2007.12.010

[5] Miyoshi, N., Takabayashi, S. Osawa, T. and Nakamura, Y. (2004) Benzyl Isothiocyanate Inhibits Excessive Superoxide Generation in Inflammatory Leukocytes: Implication for Prevention against Inflammation-Related Carcinogenesis. Carcinogenesis, 25, 567-575. http://dx.doi.org/10.1093/carcin/bgh051

[6] Faizi, S., Siddiqui, B.S., Saleem, R., Siddiqui, S., Aftab, K. and Gilani, A.H. (1994) Isolation and Structure Elucidation of New Nitrile and Mustard Oil Glycosides from Moringa oleifera and Their Effect on Blood Pressure. Journal of Natural Products, 57, 1256-1261. http://dx.doi.org/10.1021/np50111a011

[7] Khalafalla, M.M., Abdellatef, E., Dafalla, H.M., Nassrallah, A., aboul-Enein, A. and Lightfoot, D.A. (2010) Active principle from Moringa oleifera lam leaves effective against two leukemias and a hepatocarcinoma. African Journal of Biotechnolongy, 9, 8467-8471.

[8] Kumar, V., Pandey, N., Mohan, V. and Singh, R.P. (2012) Antibacterial and Antioxidant Activity of Extract of Moringa oleifera Leaves-An in Vitro Study. International Journal of Pharmaceutical Sciences Review and Research, 12, 89-94.

[9] Kumar, G.S., Kumar, B.F.B.P., Srinivasan, B.F.T.C., Nag, T.F.S., Srivastava, S.F.R., Saxena, R.F.A. and Aggarwal, A. (2013) Retinoprotective Effects of Moringa oleifera via Antioxidant, Anti-Inflammatory, and Anti-Angiogenic Mechanisms in Streptozotocin-Induced Diabetic Rats. Journal of Ocular Pharmacology and Therapeutics, 29, 419-426. http://dx.doi.org/10.1089/jop.2012.0089

[10] Budda, S., Butryee, C., Tuntipopipat, S., Rungsipipat, A., Wangnaithum, S., Lee, J.S. and Kupradinun, P. (2011) Suppressive Effects of Moringa oleifera Lam Pod against Mouse Colon Carcinogenesis Induced by Azoxymethane and Dextran Sodium Sulfate. Asian Pacific Journal of Cancer Prevention, 12, 3221-3228.

[11] Bharali, R., Tabassum, J. and Azad, M.R. (2003) Chemomodulatory Effect of Moringa oleifera, Lam, on Hepatic Carcinogen Metabolising Enzymes, Antioxidant Parameters and Skin Papillomagenesis in Mice. Asian Pacific Journal of Cancer Prevention, 4, 131-139.

[12] Brunelli, D., Tavecchio, M., Falcioni, C., Frapolli, R., Erba, E., Iori, R., Rollin, P., Barillari, J., Manzotti, C., Morazzoni, P. and D'Incalci, M. (2010) The Isothiocyanate Produced from Glucomoringin Inhibits NF-kB and Reduces Myeloma Growth in Nude Mice in Vivo. Biochemical Pharmacology, 79, 1141-1148. http://dx.doi.org/10.1016/j.bcp.2009.12.008

[13] Melesse, A., Steingass, H., Boguhn, J. and Rodehutscord, M. (2013) In Vitro Fermentation Characteristics and Effective Utilisable Crude Protein in Leaves and Green Pods of Moringa stenopetala and Moringa oleifera Cultivated at Low and Mid-Altitudes. Journal of Animal Physiology and Animal Nutrition, 97, 537-546. http://dx.doi.org/10.1111/j.1439-0396.2012.01294.x

[14] Pinto, C.E., Farias, D.F., Carvalho, A.F., Oliveira, J.T., Pereira, M.L., Grangeiro, T.B., Freire, J.E., Viana, D.A. and Vasconcelos, I.M. (2015) Food Safety Assessment of an Antifungal Protein from Moringa oleifera Seeds in an Agricultural Biotechnology Perspective. Food and Chemical Toxicology, 83, 1-9. http://dx.doi.org/10.1016/j.fct.2015.05.012

[15] Gassenschmidt, U., Jany, K.D., Tauscher, B. and Niebergall, H. (1995) Isolation and Characterization of a Flocculating Protein from Moringa oleifera Lam. Biochimica et Biophysica Acta, 1243, 477-481. 
http://dx.doi.org/10.1016/0304-4165(94)00176-X

[16] Kwaambwa, H.M., Hellsing, M.S., Rennie, A.R. and Barker, R. (2015) Interaction of Moringa oleifera Seed Protein with a Mineral Surface and the Influence of Surfactants. Journal of Colloid and Interface Science, 448, 339-346. http://dx.doi.org/10.1016/j.jcis.2015.02.033

[17] Freire, J.E., Vasconcelos, I.M., Moreno, F.B., Batista, A.B., Lobo, M.D., Pereira, M.L., Lima, J.P., Almeida, R.V., Sousa, A.J., Monteiro-Moreira, A.C., Oliveira, J.T. and Grangeiro, T.B. (2015) Mo-CBP 3 , an Antifungal Chitin-Binding Protein from Moringa oleifera Seeds, Is a Member of the 2S Albumin Family. PLoS ONE, 10, e0119871. http://dx.doi.org/10.1371/journal.pone.0119871

[18] Pavankumar, A.R., Kayathri, R., Murugan, N.A., Zhang, Q., Srivastava, V., Okoli, C., Bulone, V., Rajarao, G.K. and Agren, H. (2014) Dimerization of a Flocculent Protein from Moringa oleifera: Experimental Evidence and in Silico Interpretation. Journal of Biomolecular Structure and Dynamics, 32, 406-415. http://dx.doi.org/10.1080/07391102.2013.770374

[19] Tsaknis, J., Lalas, S., Gergis, V., Dourtoglou, V. and Spiliotis, V. (1999) Characterization of Moringa oleifera Variety Mbololo Seed Oil of Kenya. Journal of Agricultural and Food Chemistry, 47, 4495-4499. http://dx.doi.org/10.1021/jf9904214

[20] Banerji, R., Bajpai, A. and Verma, S.C. (2009) Oil and Fatty Acid Diversity in Genetically Variable Clones of Moringa oleifera from India. Journal of Oleo Science, 58, 9-16. http://dx.doi.org/10.5650/jos.58.9

[21] Sanchez-Machado, D.I., Lopez-Cervantes, J., Nunez-Gastelum, J.A., Servin de la Mora-Lopez, G., Lopez-Hernandez, J. and Paseiro-Losada, P. (2015) Effect of the Refining Process on Moringa oleifera Seed Oil Quality. Food Chemistry, 187, 53-57. http://dx.doi.org/10.1016/j.foodchem.2015.04.031

[22] Dollah, S., Abdulkarim, S.M., Ahmad, S.H., Khoramnia, A. and Ghazali, H.M. (2015) Physico-Chemical Properties of Moringa oleifera Seed Oil Enzymatically Interesterified with Palm Stearin and Palm Kernel Oil and Its Potential Application in Food. Journal of the Science of Food and Agriculture. http://dx.doi.org/10.1002/jsfa.7510

[23] Aviara, N.A., Musa, W.B., Owolarafe, O.K., Ogunsina, B.S. and Oluwole, F.A. (2015) Effect of Processing Conditions on Oil Point Pressure of Moringa oleifera Seed. Journal of Food Science and Technology, 52, 4499-4506. http://dx.doi.org/10.1007/s13197-014-1498-0

[24] Lalas, S., Gortzi, O. and Tsaknis, J. (2006) Frying Stability of Moringa stenopetala Seed Oil. Plant Foods for Human Nutrition, 61, 93-102. http://dx.doi.org/10.1007/s11130-006-0022-8

[25] Dollah, S., Abdulkarim, S.M., Ahmad, S.H., Khoramnia, A. and Ghazali, H.M. (2014) Physicochemical Properties and Potential Food Applications of Moringa oleifera Seed Oil Blended with Other Vegetable Oils. Journal of Oleo Science, 63, 811-822. http://dx.doi.org/10.5650/jos.ess13235

[26] Ogunsina, B.S., Indira, T.N., Bhatnagar, A.S., Radha, C., Debnath, S. and Gopala Krishna, A.G. (2014) Quality Characteristics and Stability of Moringa oleifera Seed Oil of Indian Origin. Journal of Food Science and Technology, 51, 503-510. http://dx.doi.org/10.1007/s13197-011-0519-5

[27] A.O.A.C. (2010) Official Methods of Analysis. $18^{\text {th }}$ Edition, Association of Official Analytical Chemists, Washington DC.

[28] Merrill, A.L. and Watt, B.K. (1973) Energy Value of Foods: Basis and Derivation. Agriculture Handbook No. 74, ARS United States Department of Agriculture, Washington DC.

[29] Borah, S., Baruah, A., Das, A. and Borah, J. (2009) Determination of Mineral Content in Commonly Consumed Leafy Vegetables. Food Analytical Methods, 2, 226-230. http://dx.doi.org/10.1007/s12161-008-9062-z

[30] Barakat, H. and Rohn, S. (2014) Effect of Different Cooking Methods on Bioactive Compounds in Vegetarian, Broccoli-Based Bars. Journal of Functional Foods, 11, 407-416. http://dx.doi.org/10.1016/j.jff.2014.10.009

[31] Lu, J., Zhao, H., Chen, J., Fan, W., Dong, J., Kong, W., Sun, J., Cao, Y. and Cai, G. (2007) Evolution of Phenolic Compounds and Antioxidant Activity during Malting. Journal of Agricultural and Food Chemistry, 55, 10994-11001. http://dx.doi.org/10.1021/jf0722710

[32] Yuan, G.F., Sun, J., Yuan, Q. and Wang, Q.M. (2009) Effects of Different Cooking Methods on Health-Promoting Compounds of Broccoli. Journal of Zhejiang University-Science B, 10, 580-588. http://dx.doi.org/10.1631/jzus.B0920051

[33] Mohdaly, A.A.A., Hassanien, M.F.R., Mahmoud, A., Sarhan, M.A. and Smetanska, I. (2012) Phenolics Extracted from Potato, Sugar Beet, and Sesame Processing By-Products. International Journal of Food Properties, 16, 1148-1168. http://dx.doi.org/10.1080/10942912.2011.578318

[34] Kumaran, A. and Joel Karunakaran, R. (2007) In Vitro Antioxidant Activities of Methanol Extracts of Five Phyllanthus Species from India. LWT-Food Science and Technology, 40, 344-352. http://dx.doi.org/10.1016/j.lwt.2005.09.011

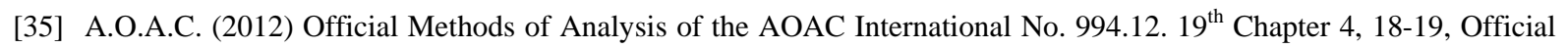


Journal of the European Communities 19.9.98, Gaithersburg, Maryland, USA.

[36] Habib, M.A. (1986) Studies on the Lipid and Protein Composition of Guava Seeds (Psidium guajava). Food Chemistry, 22, 7-16. http://dx.doi.org/10.1016/0308-8146(86)90003-8

[37] Aldai, N., Osoro, K., Barrón, L.J.R. and Nájera, A.I. (2006) Gas-Liquid Chromatographic Method for Analysing Complex Mixtures of Fatty Acids Including Conjugated Linoleic Acids (cis9trans11 and trans10cis12 Isomers) and LongChain (n-3 or n-6) Polyunsaturated Fatty Acids: Application to the Intramuscular Fat of Beef Meat. Journal of Chromatography A, 1110, 133-139. http://dx.doi.org/10.1016/j.chroma.2006.01.049

[38] Steel, R., Torrie, J. and Dickey, D. (1997) Principles and Procedures of Statistics: A Biometrical Approach. 3rd Edition, McGraw-Hill, New York.

[39] Ijarotimi, O.S., Adeoti, O.A. and Ariyo, O. (2013) Comparative Study on Nutrient Composition, Phytochemical, and Functional Characteristics of Raw, Germinated, and Fermented Moringa oleifera Seed Flour. Food Science and Nutrition, 1, 452-463. http://dx.doi.org/10.1002/fsn3.70

[40] Olagbemide, P.T. and Philip, C.N.A. (2014) Proximate Analysis and Chemical Composition of Raw and Defatted Moringa oleifera Kernel. Advances in Life Science and Technology, 24, 92-99.

[41] Ayerza, R. (2011) Seed Yield Components, Oil Content, and Fatty Acid Composition of Two Cultivars of Moringa (Moringa oleifera Lam.) Growing in the Arid Chaco of Argentina. Industrial Crops and Products, 33, 389-394. http://dx.doi.org/10.1016/j.indcrop.2010.11.003

[42] Leone, A., Fiorillo, G., Criscuoli, F., Ravasenghi, S., Santagostini, L., Fico, G., Spadafranca, A., Battezzati, A., Schiraldi, A., Pozzi, F., di Lello, S., Filippini, S. and Bertoli, S. (2015) Nutritional Characterization and Phenolic Profiling of Moringa oleifera Leaves Grown in Chad, Sahrawi Refugee Camps, and Haiti. International Journal of Molecular Sciences, 16, 18923-18937. http://dx.doi.org/10.3390/ijms160818923

[43] Govardhan Singh, R.S., Negi, P.S. and Radha, C. (2013) Phenolic Composition, Antioxidant and Antimicrobial Activities of Free and Bound Phenolic Extracts of Moringa oleifera Seed Flour. Journal of Functional Foods, 5, 1883-1891. http://dx.doi.org/10.1016/j.jff.2013.09.009

[44] Ndhlala, A.R., Mulaudzi, R., Ncube, B., Abdelgadir, H.A., du Plooy, C.P. and Van Staden, J. (2014) Antioxidant, Antimicrobial and Phytochemical Variations in Thirteen Moringa oleifera Lam. Cultivars. Molecules, 19, 10480-10494. http://dx.doi.org/10.3390/molecules190710480

[45] Sreelatha, S. and Padma, P.R. (2009) Antioxidant Activity and Total Phenolic Content of Moringa oleifera Leaves in Two Stages of Maturity. Plant Foods for Human Nutrition, 64, 303-311. http://dx.doi.org/10.1007/s11130-009-0141-0

[46] Siddhuraju, P. and Becker, K. (2003) Antioxidant Properties of Various Solvent Extracts of Total Phenolic Constituents from Three Different Agroclimatic Origins of Drumstick Tree (Moringa oleifera Lam.) Leaves. Journal of Agricultural and Food Chemistry, 51, 2144-2155. http://dx.doi.org/10.1021/jf020444+

[47] Akrem, A., Yousef, N., Begum, A., Negm, A., Meyer, A., Perbandt, M., Buck, F. and Betzel, C. (2014) Preliminary Crystallographic Analysis of a Cruciferin Protein from Seeds of Moringa oleifera. The Protein Journal, 33, $253-257$. http://dx.doi.org/10.1007/s10930-014-9558-X

[48] Lalas, S., Gortzi, O., Athanasiadis, V., Tsaknis, J. and Chinou, I. (2012) Determination of Antimicrobial Activity and Resistance to Oxidation of Moringa peregrina Seed Oil. Molecules, 17, 2330-2334. http://dx.doi.org/10.3390/molecules17032330

[49] Anwar, F. and Bhanger, M.I. (2003) Analytical Characterization of Moringa oleifera Seed Oil Grown in Temperate Regions of Pakistan. Journal of Agricultural and Food Chemistry, 51, 6558-6563. http://dx.doi.org/10.1021/jf0209894

[50] Ghazali, H.M. and Mohammed, A.S. (2011) Chapter 93-Moringa (Moringa oleifera) Seed Oil: Composition, Nutritional Aspects, and Health Attributes. In: Preedy, V.R., Watson, R.R. and Patel, V.B., Eds., Nuts and Seeds in Health and Disease Prevention, Academic Press, San Diego, 787-793. http://dx.doi.org/10.1016/B978-0-12-375688-6.10093-3

[51] Egyptian Standards (2005) Vegetable Oils as Edible Oil (Cotton Seed Oil) No. 2005/49-8. Egyptian Organization for Standardization and Quality Control.

[52] Egyptian Standards (2005) Vegetable Oils as Edible Oil (Olive and Olive Pomace Oil) No. 2005/49-2. Egyptian Organization for Standardization and Quality Control.

[53] Egyptian Standards (2005) Vegetable Oils as Edible Oil (Soybean Oil) No. 2005/49-6. Egyptian Organization for Standardization and Quality Control. 